\title{
EL BARROCO COMO ENIGMA: JEROGLÍFICOS CELESTES
}

Carmen Fernández. Galán Montemayor

Universidad Autónoma de Zacatecas

Recibido: 15 - octubre - 2015, Aprobado 22 - noviembre - 2015

\section{Resumen}

El lado fúnebre del barroco ha sido oscurecido por la posmodernidad. El término tiene tantos usos y significados que los claroscuros se vuelven estereotipos, las polifonías dejan de susurrar al oído y los dioses esconden su imagen. Éste es un intento por recuperar algunos de sus ecos olvidados y desplegar otra cara de la luna a través de la tradición novohispana de exequias fúnebres y de las difusas fronteras entre el mito y la ficción. Barroco como estilo, barroco como época y como era, su presencia siempre confusa nos devuelve la clave de los espejismos y las utopías.

Palabras clave: jeroglífico, mito, emblema, exequias.

\begin{abstract}
The baroque's funereal side has been darkened by postmodernism. The term has so many uses and meanings that chiaroscuros become stereotypes, polyphonies stop whispering in the ear and the gods hide their image. This is an attempt to recover some of its forgotten echoes, and deploy other side of the moon through the novo Hispanic tradition of funeral ceremonies and of the fuzzy boundaries between myth and fiction. Baroque as style, baroque as epoch and as age, its presence -always confused- get us back to the mirages' and utopias' key.
\end{abstract}

Keywords: hieroglyphics, myth, emblem, funeral. 


\section{El libro dentro del libro}

En torno al barroco existe una gran indefinición y difusión semántica que lo hacen proliferar hasta volverse silogismo o cifra. Quizá ante la imposibilidad de abarcar una palabra tan huidiza se ha escrito tanto sobre él y se desfigura quimérica cualquier revisión historiográfica del nombre que se aplica a distintos campos de la cultura, lo que ha tenido distintas implicaciones: ya sea elevar una categoría estética a un concepto de época, o convertir en epistemología o modernidad alternativa ${ }^{1}$ a ciertos movimientos caracterizados como barrocos.

Existen tantos barrocos cuanto artes implicadas: protestante, contrarreformista, áureo, virreinal, moderno, neobarroco, transbarroco. Aunque en apariencia disímiles, el trasfondo común es la crisis, un cambio de percepción y de conciencia ante la amenaza del final': memento mori, teatralidad, mezcla de lo divino y lo profano, pero sobre todo, predominio de la imagen sobre el texto, son características comunes a casi cualquier barroco.

La delimitación temporal y espacial del barroco es también fuente de confusión, pues como afirma Serge Gruzinski "las temporalidades de los imaginarios y las sociedades rebasan la metodología de la historia y rozan con la ficción"’3. En momentos, despreciado, y en otras ocasiones revalorado, el barroco se extiende de la arquitectura y pintura al terreno literario a principios del siglo XX con Wölfflin $^{4}$, quien establece los principios de la obra abierta y la superposición de formas. El barroco se expande aún más y se torna supra-histórico cuando Eugenio D'Ors lo convierte en un eón atemporal que se repite ${ }^{5}$ y cuando Severo Sarduy hizo un viraje temporal para aplicarlo al arte latinoamericano de su contemporaneidad ${ }^{6}$. Estos dos movimientos de eterno retorno o de explicar los mecanismos de artificialización para trasladar la retórica tradicional al lenguaje estructuralista, nietzscheano y psicoanalítico, responde a la necesidad de traducir a Europa el arte americano. A partir de entonces se consideran como paradigmas del barroco americano las obras de Lezama Lima, Alejo Carpentier, el propio Severo Sarduy y Cabrera Infante, no obstante se olvida que el modelo fundamental del barroco americano está en los virreinatos de la Corona española.

Esta reformulación del barroco para explicar la pintura y narrativa del siglo XX latinoamericano se extenderá a otras geografías hasta proponer una filosofía o estética neobarroca ${ }^{7}$ que tiende a lo limítrofe y a la imperfección, como los poemas

1 Barroco como modernidad y multiculturalismo, mestizaje y epistemología nómada es la propuesta de Bolívar Echeverría en La modernidad del barroco, Era, México, 1998.

2 Véase al respecto: Carmen F. Galán, "La luz como metáfora histórica”, en Semiosis, Tercera época, vol. V, núm. 9, Instituto de Investigaciones Lingüístico-Literarias, Universidad Veracruzana, enero-junio de 2009, ISSN 0187-9316, Latindex.

3 Serge Gruzinski, La guerra de las imágenes. De Cristóbal Colón a Blade Runner (1492-2019), FCE, México, 2013.

4 Existen otros autores precursores del barroco como: Eliot, Valery, Mallarmé, la generación del 27, aunque se dice que la obra de Oswald Spengler donde el término se extiende a la filosofía, la política, etc. Cfr. Víctor Manuel de Aguiar e Silva, Teoría de la literatura, Gredos, Madrid, 1999.

5 Eugenio D’Ors, Lo barroco, Tecnos, Madrid, 1993.

6 Severo Sarduy, El barroco y neobarroco. El cuenco de Plata, Buenos Aires, 2011.

7 Omar Calabresse, La era neobarroca, Cátedra, Madrid, 1987. 
galaxia y el transbarroco de Haroldo Campos donde la ciencia y la literatura se rencuentran. En este escenario el barroco se entiende más como una práctica de lectura que como una poética o manifiesto: lecturas radiales, desplazamiento del espectador, significado siempre diferido, lo que Sarduy explicaba como un "oscurecimiento ante la libertad vigilada", "anagrama como idioma oprimido", ¿fracaso de la representación y repetición obsesiva?

El eje ya no es ni el autor, ni el texto y al multiplicarse las lecturas, se intenta buscar en las antiguas artes de la memoria artificial y en las máquinas generativas de la poesía de Caramuel, la explicación por la desconfianza en el libro, que el saber se vuelva sueño ${ }^{8}$, que el teatro torne confusas las fronteras entre el arte y la vida. Lo maravilloso es, así, aquello que el otro no alcanza a comprender: realismo mágico para descubrir verdades y explicar la literatura americana que comienza con Sor Juana y llega hasta Roberto Bolaños?.

Las implicaciones de trasponer categorías del barroco a la cultura contemporánea van desde la borradura temporal del eón que se repite in illo tempore, al pensamiento descentrado que conduce a la relatividad postmoderna. Muy lejano quedó el hombre barroco suspendido entre el abismo del infinito en peregrinaje místico buscando la verdad. Lo anterior suscita numerosas preguntas:

¿Es el barroco conjuctio oppositorum capaz de conciliar cismas (lo claro y lo oscuro, Reforma y la Contrarreforma, lo moderno y lo postmoderno) o es diseminación incalculable?

¿Crisis del arte o arte de crisis? ¿Arte efímero o permanente? ¿'Totalidad o detalle? ¿Conciencia de lo macro o de lo micro ante el universo que se expande?

Sin el afán de responder estas preguntas, lo siguiente es una reflexión en torno al lado mítico y alegórico del barroco vinculado a la esfera ritual y a la fiesta dentro del mundo virreinal, paraje donde se gesta una fórmula de escritura que lleva al enigma, a la verdad conceptuosa y accesible por el ingenio, al convencimiento visual tejido de citas, intertextualidades y anagramas. El barroco hay que repensarlo en función del mito, la ficción y la magia, para volverlo más indescifrable.

\section{Del emblema al jeroglífico}

América es el sitio donde se mostró la eficacia de los discursos visuales que en la coyuntura de la Contrarreforma se convirtieron en una pedagogía de masas muy convincente. Esta colonización a través de la imagen aparece en tanto los evangelizadores del Nuevo Mundo se encuentran con las escrituras pictográficas, dando lugar a los catecismos en imágenes; de manera paulatina, se va integrando un vasto repertorio simbólico renacentista en las distintas manifestaciones del arte efímero que se presentan dentro la fiesta barroca donde los géneros literarios son una explosión de formas.

Fueron pocas las obras que en Nueva España tuvieron la fortuna de llegar a la imprenta, sin embargo, las élites novohispanas patrocinaron la publicación de

8 Fernando R. de la Flor, Era melancólica. Figuras del imaginario barroco, José J. de Olaeta Editor-Ediciones UIB, Barcelona, 2007.

9 Samuel Arriarán, Barroco y neobarroco en América Latina. Estudios sobre la otra modernidad, Itaca, México, 2007. 
sermones o relaciones de festejos que muestran la recepción del mundo simbólico europeo que servía de fuente de inspiración para pintores y poetas. La emblemática es lugar donde se condensan múltiples tradiciones: bestiarios medievales, heráldica y alquimia junto a los acervos míticos grecolatino y helénico, que en la mirada neoplatónica convierte al jeroglífico en fuente de sabiduría universal.

Como tipo textual el emblema consta de un grabado, mote y epigrama, en una relación de complementariedad entre imagen y escritura latina. Esta moda intelectual se denominó indiferenciadamente emblema, empresa y jeroglífico, no obstante que las Hieroglyphicas de Horapolo y Piero Valeriano, partan de otros artificios. Cabe entonces distinguir el jeroglífico de los desciframientos de Athanasius Kircher ${ }^{10}$, del género literario que se cultivó en pintura y poesía. En su Arte poética española, Díaz Rengifo dice que los poetas utilizan los hieroglyphicos "para exprimir alguna agudeza o sentencia, y procuran que las figuras o propiedades de ellos convengan al objeto al que las dirigen ${ }^{11}$ ". Desde el punto de vista pictórico, Palomino de Castro y Velasco define al geroglifico [sic] "como una metáfora que incluye algún concepto doctrinal", y especifica que se usan en funerales, coronaciones de príncipes, canonizaciones de santos, entre otras festividades ${ }^{12}$.

De la utilización del jeroglífico en la tradición hispana da cuenta Víctor Mínguez, quien realiza un inventario de los emblemas imperiales que garantizaron siglos de lealtad y que se manifiestan como jeroglífico festivo en la Corona de Castilla, Aragón, los reinos de Navarra y Portugal, Nueva España y Perú ${ }^{13}$. Para el caso de la Nueva España Mínguez enumera las relaciones de exequias de Isidro Sarillana, Agustín de Mora, José de Villerías, Carlos Cadena, junto con algunas crónicas anónimas, en este listado falta incluir los obeliscos dedicados a Luis I en Zacatecas y a Carlos III en Puebla ${ }^{14}$ que son parte de esta herencia muy cercana al emblema.

En la Nueva España sobresale el uso del jeroglífico con fines funerarios, tradición de exequias que describió Francisco de la Maza en 1946 ${ }^{15}$. Las primeras piras funerarias en México fueron las dedicadas a Cortés y la de Carlos V realizada por Cervantes de Salazar y editada en 1560, que se considera el modelo por excelencia, donde ya aparece la construcción de emblemas, no aún denominados jeroglíficos.

10 Ignacio Gómez de Liaño, Athanasius Kircher: Itinerario del éxtasis o imágenes de un saber universal, Siruela, Madrid, 1985.

11 Juan Díaz Rengifo, Arte poética española, Imprenta de María Marti, viuda administrada de Mauro Marti, Barcelona, 1754, [Biblioteca de Colecciones Especiales Elías Amador], p. 177

12 Antonio Palomino de Castro y Velasco, El museo pictórico y escala óptica, Imprenta de Sancha, DCCX CV, [BEA], p. 63.

13 Cfr. Víctor Mínguez, "Imágenes jeroglíficas para un imperio en fiesta" en: Relaciones. Estudios de historia y sociedad, 119, verano 2009, vol. XXX, El Colegio de Michoacán, pp. 81-112. Para el caso de Lima, véase también: Adita Allo Manero, "Aportación al estudio de las exequias reales en Hispanoamérica...", Anuario del Departamento de Historia y Teoría del Arte 1, Madrid, 1989.

14 Del obelisco de la ciudad de Puebla de los Ángeles hay una edición facsímil del INAH-SEP con introducción de Castro Morales. Del Obeliscus Zacatenus... hay estudios realizados por Federico Sesscose, y una edición-traducción y estudio en Obelisco para el ocaso de un príncipe, editado por la UAZ en 2011.

15 Francisco de la Maza, Las piras funerarias en la bistoria del arte y de México. Grabados, litografías y documentos de los siglos XVI al XIX, Anales del Instituto de Investigaciones Estéticas, Imprenta Universitaria, México, 1946. 
El túmulo imperial de la gran ciudad de México es un libro que condensa los géneros de relación, écfrasis y emblema junto a varias fórmulas de poesía y dos láminas sobre la estructura del catafalco, no así de las pinturas que lo adornaban. Algunos libros de exequias posteriores editados en Nueva España contendrán dibujos de las imágenes que adornaban los túmulos funerarios, como los célebres geroglificos (alrededor de 16 ilustraciones) de Llanto de Occidente en el ocaso del más claro Sol de las Españas, impreso en 1666 por la viuda de Bernardo Calderón, muy distintos de los hieroglificos de Llanto de las estrellas... ${ }^{16}$ de José de Villerías impreso en 1725 por Bernardo de Hogal con alrededor de 33 grabados firmados por Sylu [il] e inspirados en las pinturas realizadas por Francisco Martínez que adornaban el túmulo a Luis I.

Llanto de las estrellas continúa la metáfora-metonimia del sol eclipsado y vuelto a nacer, alusivo a la sucesión dinástica, con un matiz especial por la circunstancia de la abdicación de Felipe V: "Todas las veces que se viere en el cielo dos soles, habrá inundación. Y así vimos lucir en el cielo dos soles Felipe V y Luis I. [...] Anochesióse el Sol en el oriente. Muerte del sol." De este modo Villerías forma obtusas imágenes relativas a los cuerpos celestes, por ejemplo, la antítesis entre encenderse la fiebre (que acabó con la vida del joven monarca) y el apagarse la vida, de lo deduce que "habiendo aquella muerte seguido la noche, la misma que escondió la luz, descubrió las estrellas" porque enterrado el Sol solo podían ésta arderle por hachas, refiriéndose a las velas que adornan el túmulo.

La obra es una relación de exequias que describe minuciosamente la arquitectura del túmulo y las honras fúnebres así como los actores involucrados en el evento: arquitectos, pintores, predicadores...; contiene además de los hieroglificos (con empresas, sonetos, liras y epigramas), una oración fúnebre y el sermón que se predicó en la Iglesia Metropolitana de México. Este elaboradísimo aparato simbólico que acompaña al ritual de lealtad va dirigido a múltiples destinatarios, y no cabe duda que el argumento desarrollado en Llanto de las estrellas sólo era comprensible para la élite letrada que requería conocimientos de latín, retórica y teología para comprenderlos en su totalidad con base en innumerables referencias librescas. Los emblemas-jeroglíficos eran susceptibles de "recreación por parte del espectador. Suponía el ejercicio del ingenio para desentrañar la agudeza, resolver el enigma o reformular el concepto ${ }^{17}$ ".

Lo interesante en este libro es cómo las fronteras del mito y la astrología se cruzan oscilando del terreno de la verdad a la fantasía. El motivo de los astros está fundamentado tanto en la astronomía como en la astrología judiciaria, se precisa la posición de los astros para el día del nacimiento y el día de la muerte de Luis I, hay una serie de hieroglificos destinados a los signos zodiacales y el orden de las estatuas del túmulo sigue el orden de los planetas. Asimismo hay un trasfondo

16 Llanto de las estrellas al ocaso del sol anochecido en el Oriente. Solemnes exequias que a la augusta memoria del serenísimo y potentísimo señor don Luis I, rey de la Españas, celebró el Excelentísimo Señor Don Juan de Acuña [...] y cuya relación escribe Don José de Villerías, Impreso por José Bernardo de Hogal, México, 1725. [Biblioteca Nacional de México]

17 Arnulfo Herrera Curiel, "Los verdaderos sentidos de un emblema" en: Bárbara Skinfill Nogal y Eloy Gómez Bravo (eds.), Las dimensiones del arte emblemático, El Colegio de Michoacán-Conacyt, México, 2002, p. 339. 
neoplatónico y hermético en el momento que dice "los astros son los ojos del mundo" y que la gentilidad creía que con versos mágicos podrían arrastrar del cielo a la tierra, los astros.

Del zenit al ocaso, nadir y oriente, Villerías traslada lo caduco a lo eterno, lo terreno a lo celeste y dice que las estrellas caen de dos maneras: cuando ciertas impresiones meteóricas aparecen y desaparecen súbitamente, y cuando los verdaderos astros se esconden a nuestro horizonte. Luis I es el cometa arrebatado, Faetón quemado por el Sol: detrás de todo hay una razón matemática, una cifra, un laberinto de palabras que lleva a la luz.

Del nombre de este gran Príncipe no han faltado ingenios ociosos, que hayan hecho diversas consideraciones, como es observar que Ludovicus Rex en anagrama vale lo mismo que $\mathrm{O}$ lux vir decus, y decir que en la etimología se interpreta como Lucen do vincens ${ }^{18}$.

Los jeroglíficos celestes son un espejo que al encriptar revelan otra cara del barroco, aunque sean primordialmente laudatorios, conllevan ecos de enigma y de un conocimiento que intenta convertir príncipes en héroes mitológicos. Si la línea ideológica traza indeterminadas las fronteras de la realidad, se puede decir que los jeroglíficos de Villerías son ficciones de sabiduría, como las denomina Thomas Pavel ${ }^{19}$, y que se trata de un proceso de expansión de la ficción en el mito, es decir, que el acervo mítico grecolatino en el marco del ritual de exequiasse hace vigente, las imágenes jeroglíficas y las estatuas en el catafalco traen a la presencia los símbolos que conviene recordar para garantizar la pervivencia de un imperio.

Lo anterior nos lleva a nuevas preguntas sobre la vigencia del barroco como cultura de masas y sobre los mecanismos para la fabricación de símbolos que ya no contienen virtudes ni contemplan las estrellas, pues las imágenes circulan enescrituras líquidas y nuevas ritualidades, mejor decir, virtualidades. Actualmente arte y ciencia parecen disociados porque se han vuelto autorreferenciales e intertextuales, y frente a la incertidumbre de la representación, el jeroglífico es una verdad en clave, una invitación al desciframiento.

El barroco es siempre cambio, transustanciación, por eso nadie mejor que Mercurio (Hermes) como estatua en el túmulo nos remite al conflicto eterno del hombre barroco: lo que nos mantiene en pie es la lucha entre cuerpo y alma, tierra y fuego...

\section{Bibliografía}

Carmen F. Galán, "La luz como metáfora histórica”, en Semiosis, Tercera época, vol. V, núm. 9, Instituto de Investigaciones Lingüístico-Literarias, Universidad Veracruzana, enero-junio de 2009, ISSN 0187-9316, Latindex.

18 Traduciendo los anagramas el sentido aproximado es: Luis rey es igual a hombre adornado de luz y gloria, y a resplandeciente, triunfa. Ibid, p. 103.

19 Thomas Pavel, "Las fronteras de la ficción", en Teorías de la ficción literaria, Antonio Garrido compilador, Arco/Libros, Madrid, 1997. 
Serge Gruzinski, La guerra de las imágenes. De Cristóbal Colón a Blade Runner (14922019), FCE, México, 2013.

Eugenio D’Ors, Lo barroco, Tecnos, Madrid, 1993.

Severo Sarduy, El barroco y neobarroco, El cuenco de Plata, Buenos Aires, 2011.

Omar Calabresse, La era neobarroca, Cátedra, Madrid, 1987.

Fernando R. de la Flor, Era melancólica. Figuras del imaginario barroco, José J. de Olaeta Editor-Ediciones UIB, Barcelona, 2007.

Samuel Arriarán, Barroco y neobarroco en América Latina. Estudios sobre la otra modernidad, Itaca, México, 2007.

Ignacio Gómez de Liaño, Athanasius Kircher, Itinerario del éxtasis o imágenes de un saber universal, Siruela, Madrid, 1985.

Juan Díaz Rengifo, Arte poética española, Imprenta de María Marti, viuda administrada de Mauro Marti, Barcelona, 1754, [Biblioteca de Colecciones Especiales Elías Amador], p. 177

Antonio Palomino de Castro y Velasco, El museo pictórico y escala óptica, Imprenta de Sancha, DCCXCV, [BEA], p. 63

Víctor Mínguez, "Imágenes jeroglíficas para un imperio en fiesta”, en Relaciones. Estudios de historia y sociedad, 119, verano 2009, vol. XXX, El Colegio de Michoacán, pp. 81-112. Para el caso de Lima, véase también: Adita Allo Manero, "Aportación al estudio de las exequias reales en Hispanoamérica...", Anuario del Departamento de Historia y Teoría del Arte 1, Madrid, 1989.

Del obelisco de la ciudad de Puebla de los Ángeles hay una edición facsímil del INAH-SEP con introducción de Castro Morales. Del Obeliscus Zacatenus... hay estudios realizados por Federico Sesscose, y una edición-traducción y estudio en Obelisco para el ocaso de un príncipe, editado por la UAZ en 2011.

Francisco de la Maza, Las piras funerarias en la historia del arte y de México. Grabados, litografías y documentos de los siglos XVI al XIX, Anales del Instituto de Investigaciones Estéticas, Imprenta Universitaria, México, 1946.

Llanto de las estrellas al ocaso del sol anochecido en el Oriente. Solemnes exequias que a la augusta memoria del serenísimo y potentísimo señor don Luis I, rey de la Españas, celebró el Excelentísimo Señor Don Juan de Acuña [...] y cuya relación escribe Don José de Villerías, Impreso por José Bernardo de Hogal, México, 1725. [Biblioteca Nacional de México]

Arnulfo Herrera Curiel, "Los verdaderos sentidos de un emblema”, en Bárbara Skinfill Nogal y Eloy Gómez Bravo (eds.), Las dimensiones del arte emblemático, El Colegio de Michoacán-Conacyt, México, 2002, p. 339.

Thomas Pavel, "Las fronteras de la ficción”, en Teorías de la ficción literaria, Antonio Garrido compilador, Arco/Libros, Madrid, 1997. 